\title{
METONYMY, METAPHOR, PATROKLOS, ACHILLES
}

\author{
Leonard Muellner* * Professor Emeritus \\ of Classical Studies, \\ Brandeis University \\ Recebido em: 22/11/2019 \\ Aprovado em: 12/12/2019 \\ (Waltham MA USA). \\ Senior Fellow, Center \\ for Hellenic Studies \\ (Washington DC \\ USA). \\ muellner@brandeis.edu
}

\begin{abstract}
This paper proposes an analysis of the relationship between tenor and vehicle in the simile that Achilles speaks to the weeping Patroklos at Iliad 16.5-11. Conceiving metaphor as based on resemblance (and, inevitably, difference) between tenor and vehicle and metonymy as based on attachment or connection between them, the simile is interpreted as a metaphor for the fused relationship between Achilles and Patroklos (the tenor) whose vehicle is the metonymic relationship between a mother fleeing both the catastrophic, violent consequences of war on women and at the same time her very own child who is desperately trying to stay connected to her mother by grasping at her clothing. The analysis invokes as a striking parallel the research of the pediatric psychoanalyst D. W. Winnicott on the birth of metaphor (in the form of a so-called transitional object) that results from the process of a child's detachment at weaning from her mother.
\end{abstract}

KEYWORDS: Metonymy; metaphor; attachment; resemblance; philotēs; nēpios; therapōn; transitional object.

$$
\text { METONÍMLA, METÁFORA, PÁTROCLO, AQUILES }
$$

RESUMO: Este artigo propõe uma análise da relação entre teor e veículo no símile que Aquiles diz para Pátroclo que chora em Ilíada 16, 5-11. Concebendo a metáfora como baseada na semelhança (e, inevitavelmente, na diferença) entre teor e veículo, e a metonímia como baseada na ligação ou conexão entre eles, o símile é interpretado como uma metáfora para a relação unificada entre Aquiles e Pátroclo (o teor), cujo veículo é a relação metonímica entre uma mãe fugindo tanto das consequências catastróficas e violentas da guerra sobre as mulheres quanto, ao mesmo tempo, de sua própria criança que tenta desesperadamente permanecer conectada à sua mãe, agarrando sua roupa. A análise invoca como um paralelo impressionante a pesquisa do psicanalista pediatra D. W. Winnicot sobre 
o nascimento da metáfora (na forma de um assim chamado objeto transicional) que resulta do processo de desligamento de uma criança, no desmame, de sua mãe.

PALAVRAS-CHAVE: Metonímia; metáfora; ligação; semelhança; philótēs; népios; therápōn; objeto transicional.

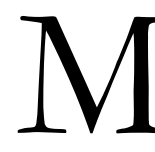

$\mathrm{y}$ intention is to explicate the simile that Achilles speaks at the beginning of Iliad 16, once he lays eyes upon Patroklos weeping like a dark-watered spring that drips from a steep rock face (16.3-4). Here is the text of Achilles' speech and an attempt at a translation of it:

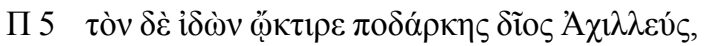

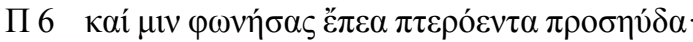

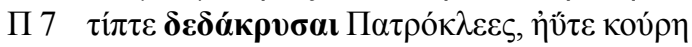

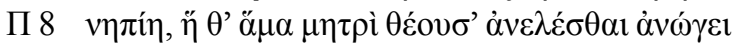

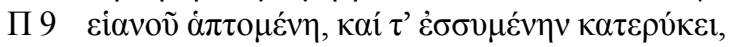

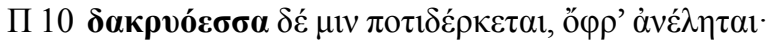

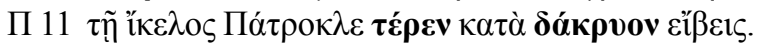

5 Once he saw him [Patroklos], radiant, swift-footed Achilles pitied him,

6 and he activated his voice and addressed [him] feathered words:

7 "Why are you in tears, Patroklos, like a girl,

8 a nēpiè one, who runs alongside her mother, begs her to pick her up,

9 attaches herself to her fine robe, and tries to stop her as she [her mother] rushes headlong,

10 and with tears in her eyes she [the girl] looks at her, so that she might pick her up;

11 like her, Patroklos, you are shedding a tender tear..."

To my mind, this simile not only illuminates Achilles' immediate response to Patroklos at the start of the sixteenth rhapsody, but also the whole way that he relates to Patroklos throughout the episode and the rest of the poem. In effect, it stands as an emblem over the whole narrative that follows.

I wish to state at the outset my views on the Homeric similes in general and, in particular, how I understand the term 'metonymy' in contrast to the term 'metaphor'. I have nothing especially new to say about these topics, but let my views be as transparent as possible. ${ }^{1}$ My analysis of metaphor and metonymy goes back to two sources: the British literary critic I. A. Richards, who wrote classic works on rhetoric and literary criticism in the 1920's and '30's, and the monograph entitled Masterpieces of Metonymy by Gregory Nagy, published in 2015 (online) / 2016 (in print). Richards's works established the standard

\footnotetext{
${ }^{1}$ For a more complete treatment and more texts to support it, see my earlier work on a Homeric simile cited in note 7 below.
} 
terminology for metaphor in formal terms as composed of two things, a tenor, the thing being referenced (in our case, the epic narrative), and a vehicle, the image that refers to the tenor (or in our case, the simile); metonymy has the same two constituents. ${ }^{2}$ For a global definition of the relationship between the two in metaphor, I adopt a slightly modified version of the operative definition of Nagy: the relation between tenor and vehicle in a metaphor is based on likeness and therefore also difference (since one cannot have likeness without difference). ${ }^{3}$ For example, in the simile above, one can say that the tenor is the weeping Patroklos and the vehicle, the image of the weeping girl trying to slow down her hurrying mother and make her pick her up; the metaphor depends on the similarity and also the difference between tenor and vehicle. As Richards' terminology makes clear, and as the literary theoretician Nelson Goodman stated explicitly, ${ }^{4}$ simile reduces to metaphor. The formal difference between the two, the actual occurrence of a word meaning 'like', is insignificant, given that likeness is an inherent aspect of metaphor. There are situations in which the addition of a word meaning 'like' before an image has a distancing or defamiliarizing effect that is different from the immediacy of an image when no such an introductory word is used, but such an effect is non-essential and can be generated by other means, such as increasing the degree of difference between tenor and vehicle at the expense of their likeness.

By way of comparison, metonymy is the establishment of a relationship between tenor and vehicle that is based on attachment or connection, either physical or psychological. I once attended a dinner party where the guests were seated at a round table. On my right was a young child, and beside her was her father; her mother was about one third of the way around the table, with two or three other guests on either side of her. At one point early in the meal, the child pointed at the person to the right of her mother and asked her father, "Who is that sitting next to Mommy's eye?" Her expression "Mommy's eye", in which she used a striking object in her own visual field that was connected to or in her mind associated with the sight of her mother, namely, her eye, to refer to her mother herself, is an example of metonymy. Needless to say, this five- or six-year old child was neither a poet nor a rhetorician, so my example also illustrates the fact that metonymy is a natural language phenomenon. In fact, it is arguable that metonymy is, literally, metaphor's ontogenetic precursor; discussion on that point will follow.

To sum up the discussion so far, a metaphoric relationship between tenor and vehicle is one of likeness (as well as, of course, difference); a metonymic relationship is one of connectedness, contiguity, or attachment. Metonymy and metaphor are relation-specific terms that are basic to verbal art, but I want to suggest that they can also describe another kind of relationship, the one between two human beings, in which one is the tenor, the other the vehicle, depending on one's point of view. In this way, two people can be either 'metonymic' friends, in which the relationship of one friend to the other is a matter of

\footnotetext{
${ }^{2}$ Richards, 1971, p. 89-112, Lecture V, "Metaphor", especially p. 96.

${ }^{3}$ Nagy, 2016, 0\$01-0\$03.

${ }^{4}$ Goodman, 1968, p. 77-78: "simile reduces to metaphor; or rather, the difference between simile and metaphor is negligible”, who cites Black, 1962, p. 37.
} 
connection - perhaps you have heard couples refer to themselves as 'attached at the hip'5: such couples sometimes have a hard time realizing where one member of the pair begins and the other leaves off. To put it another way, in a metonymy, tenor and vehicle coalesce, so when the child spoke of her 'mommy's eye', to her, the eye was her mother. On the other hand, the relationship between friends also can be metaphoric, where likeness and difference are both firmly present to mind, so that a metaphor even brings to mind the difference as well as the likeness between tenor and vehicle. I believe and wish to demonstrate that the association of these two kinds of verbal relationships with two kinds of human ones is operative in Homeric and subsequent Greek culture. For instance, in Homer, a philos - this word is usually translated 'friend' in English, but 'dear one' is probably a better way - can be another person who is like you and different from you, such as your son, but your very own limbs or your knees can also be phila, in that they are attached to you. ${ }^{6} \mathrm{~A}$ proverb in the form of a question and its answer that is ascribed to Aristotle and others is important and

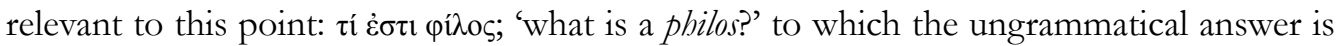
$\ddot{\alpha} \lambda \lambda \alpha_{0} \dot{\varepsilon} \gamma \omega$, 'another I'. Given the metonymic and metaphoric usages of philos, this response raises a question: is the 'other I' to be conceived as like the first 'I' and also different from it, or attached/connected to it? It is an important and pertinent question, but for the moment, it is worth remembering that the Latin translation of the answer in the proverb, alter ego, which Cicero applied to an especially close friend, is now a technical term in psychology for a person's 'second self'.

Before I return to Iliad 16 and the simile about the girl, I want to make three general points about Homeric similes on the basis of work done previously:

- From my own work and the work of colleagues like W. C. Scott, ${ }^{7}$ I believe that the Homeric simile is as traditional and systematic in diction and embedded function as the rest of Homeric poetry. Like Homeric formula and theme, similes have become part of the compositional system of the epic over the course of generations upon generations of singers interacting with audiences. Given the traditionality of the diction and the fact that, as Albert Lord put it, all elements in epic have depth, ${ }^{8} \mathrm{I}$ take my task to be the study of the language of similes and their functions in context, in order to rebuild the associations and resonances that they had for the Epic singers and their listeners as best we can at this remove in time and space from their generation in performance. Understanding the way that a given simile relates to other similes that are like

\footnotetext{
${ }^{5}$ Worthy of note is the metaphorical use of the notion of attachment to describe a metonymy.

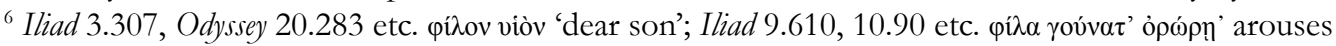

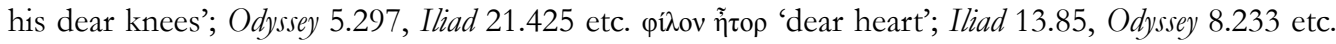

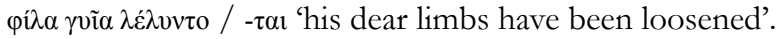

${ }^{7}$ Scott, 1974; Scott, 2009; Muellner, 1990.

${ }^{8}$ Lord, 1968, p. 46: "All the elements in traditional poetry have depth, and our task is to plumb their sometimes hidden recesses; for there will meaning be found."
} 
it is a crucial first step, because a tacit conspiracy of meaning and conventions develops over time between traditional poet and traditional audience, and $a$ fortiori in a subsystem of the poetic tradition that is so clearly prone to both expansion and contraction. All the words and meanings that specify the relationship between tenor and vehicle may not be on the surface of the simile, and that is also why it sometimes seems as though there are more elements on the surface than we know what to do with. What we are missing and have to reconstruct is the resonance and depth of all the elements that connect tenor and vehicle, both the surfeit and the lack.

- Secondly, and as a consequence of the first point, both the language of similes and the relationship between tenor and vehicle in them are as precise and meaningful as every other element in Homeric poetry. Despite the formal (but not obligatory) presence of a so-called tertium comparationis, a term shared between tenor and vehicle like the words for tears and weeping printed in bold in the citation of the simile of Iliad 16 given above, that shared term is merely a symptom of the relationship between them, not its sum total. Likewise, when

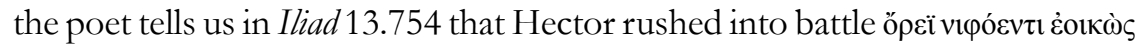
'like a snowy mountain' we do not understand what the relationship is between tenor and vehicle. That does not mean that the poet made a mistake, or that he is dwelling, in such a highly compressed format, only on an extraneous detail. It just means that we do not have enough parallels or an interpreter who can, as yet, make sense of the metaphor. Again, we need to unpack the resonance and depth of the diction that we do have to recover the meaning of such highly conventional tropes.

- Last general point: it used to be thought that the "world of the similes" was the "world of the Homeric audience," a comforting and friendly reference point for the audience to understand the older epic world in terms of their own daily experience. This hypothesis simply does not work. Not only are there similes about events that by definition no human audience has ever seen - the battle of the cranes and pygmies in a simile at the beginning of Iliad 3, for example, happens on the far side of the Okeanos, from which few if any have returned - but there are also similes about events that take place in the epic world itself, like the simile about Odysseus weeping like a captive woman in Odyssey 8.523-531, and, as we will see just below, the simile in Iliad 16 that is my central topic. On the other hand, what does seem to apply in general to the diction of Homeric similes is that they are the domain of the particle $\tau \varepsilon$, the same $\tau \varepsilon$ that makes an indicative sentence into a proverb, as in $\pi \alpha \theta \dot{\omega} v \delta \varepsilon \dot{\varepsilon} \tau \varepsilon$ vímıৎ ह̌ $\gamma v \omega$ 'a neppios learns by suffering'. In other words, by contrast with the narrative, which tells of a sequence of events each of which happened once (though they will have already been retold many times over), the similes tell of events that happen over and over again. 
To return to the wording of Iliad 16.5-11:

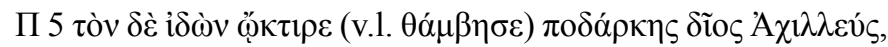

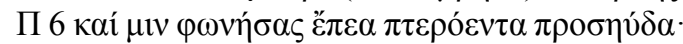

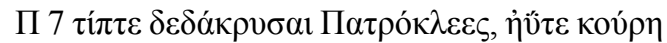

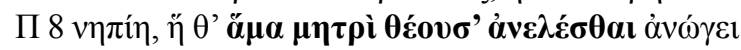

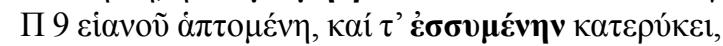

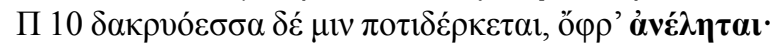

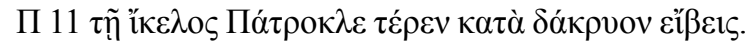

5 Once he [Achilles] saw him [Patroklos], radiant, swift-footed Achilles pitied (variant: was astounded at) him,

6 and he activated his voice and addressed [him] winged words:

7 "Why are you in tears, Patroklos, like a girl,

8 a nêpiè one, who running alongside her mother, begs her to pick her up

9 attaching herself to [baptomene] her fine robe [beianou], and she tries to stop her rushing,

10 and with tears in her eyes she looks at her, that she might pick her up;

11 like her, Patroklos, you are shedding a soft tear..."

From ancient times until 2008, there was no question as to which thematic context this simile falls into relative to other similes. The unspoken and unchallenged assumption was that this was a domestic scene like the one comparing Athena protecting Menelaos to a mother shooing flies from a sleeping baby or the one comparing Teucer hiding behind Ajax's shield to a child being protected by its mother, or like any of the many similes that feature either women spinning, giving birth, or arguing in the street or children stirring up nests of wasps or building and then destroying sand castles. But in 2008 Kathy Gaca set out to prove that the context was in fact the same as the simile in Odyssey 8.523-531, the one mentioned just above, namely, a scene that compares Odysseus weeping at the song of Demodocus about the capture of Troy to the weeping of a woman draped over the body of her beloved husband while her captors shove her with the butts of the spears, off into a life of sexual and domestic enslavement that awaits her.' The key points of her analysis are the words that I have highlighted in bold in the handout, beginning with the words

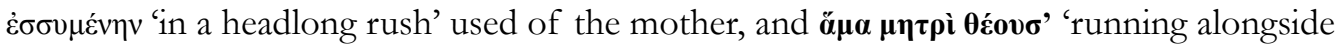

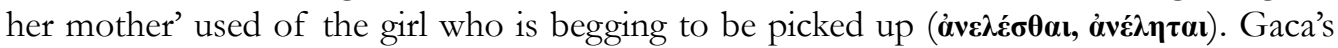

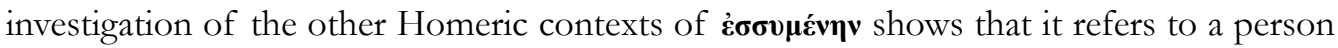
in an intense, focussed state of energy, often someone fleeing in fear of being captured; and, like Eustathius, she rightly takes the fact that the girl in the simile is running to mean that the mother is running as well. In addition, she can point to descriptions of secondary warfare, the horrifying aftermath once the battle between men has been won and lost, in Greek and Roman sources from Euripides to Eustathius' account of the capture of his own city, Thessaloniki. In some of these sources, which are indeed relevant to this simile

\footnotetext{
${ }^{9}$ Gaca, 2008.
} 
no matter how much they post-date the epic, women are said to flee victorious warriors in such terror that they outpace their own children, exactly in the way described in the simile.

The context in which the simile falls relative to other similes is significant, because we need it in order to rebuild the resonance of its diction and to understand its relationship to the epic narrative. To explore what that may be, we may begin with what Achilles says right after the simile:

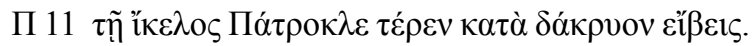

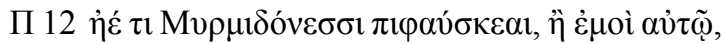

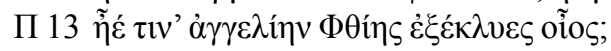

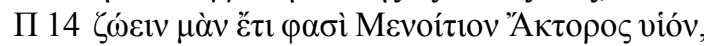

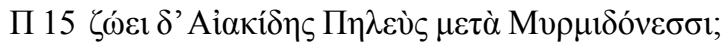

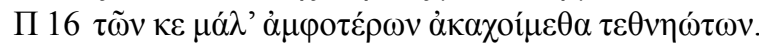

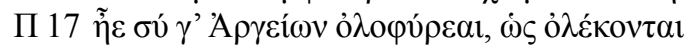

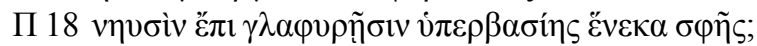

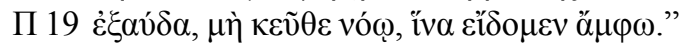

11 Like her, Patroklos, you are shedding a soft tear.

12 Are you trying to reveal something to the Myrmidons or to me personally, 13 or did you hear a message by yourself from Phthia?

14 Do they say that Menoitios, the son of Aktor, is alive,

15 and that Peleus the son of Aeacus lives with the Myrmidons?

16 For both of them we would be sorely aggrieved had they died.

17 Or are you mourning for the Argives, for the way they are perishing

18 by the hollow ships, on account of their overstepping?

19 Speak out, don't hide it in your mind, so that we may both know."

These three beautifully structured questions and their reverse-ordered answers, followed by a final formulaic line that is otherwise twice attested in lines spoken by Thetis consoling Achilles himself - in other words, in the context of a mother consoling her child - these lines are focused on one notion, namely, that Patroklos' tears are tears of grief at the death of either his own or Achilles' father or at the death of the Argives themselves, as a group. Gaca rightly points out that the tears of the girl are no more trivial than those of Hector's rejected son, Astyanax, as described unforgettably by Andromache at the end of Iliad 22 in another narrative of post-war horror for women and children. Here is Gaca's view of the relationship between tenor and vehicle, between Patroklos and the girl in the simile:

The young girl [...] is in a similar state of grief: first because her tears are pouring forth like those of Patroclus and Astyanax, and second, because she and her mother are trying to flee with no armed male relatives either still alive or sufficiently able-bodied to protect them or to help facilitate their escape. The adult male kin and defenders in the girl's and mother's community are thus understood as either wounded, mangled, or killed, with the girl's father presumably a casualty among them, just like the Greeks whose impending 
devastation has overwhelmed Patroklos. The correlation between Patroclus' and the young girl's flowing tears and their bereavement and sense of urgency is crafted by the succinct logic of this Homeric simile and the traditional significance of outpouring tears in the Iliad. $^{10}$

I am in complete sympathy with Gaca's overall approach, which is to discover the systematic associations of the diction in similes. By their conventional and traditional nature and by virtue of their tendency to expansion and contraction, similes can freely omit relevant items that are tacitly brought to mind by singer and listener. However, in this particular simile, there is more to the relationship between tenor and vehicle than this vitally helpful contribution on its context and the extreme pathos that it evokes. If we ask of this text, "why is the girl in tears?", the focus is squarely, explicitly and repeatedly, on the desire of the girl to be picked up by her running mother, on the way that she grasps her mother's fine garment - Gaca rightly points out that Homeric غ́avó refers to finely woven cloth, the clothing of an aristocratic woman - and also on the way that the girl tries to restrain her rushing mother in her desire to be picked up. In other words, the simplest and most straightforward interpretation is that the girl in the simile is in tears because she sees that her mother is about to abandon her, and we experience that traumatic fear through her eyes, through her tearful gaze that cries out for help.

I will come back to the important matter of the garment in a moment, but it is worth noting that in the girl's traumatic fear of being bereft of her mother, we have a precise analogue to the urgent fear that Achilles empathically attributes to Patroklos, the fear of being bereft of his own or Achilles' father - it is important for my argument to note that these are specified as equally disastrous for both heroes - or of the rest of their warrior companions, to whom they are bound by deep ties of affection, of philotes, the bonds of affection at work between blood relatives, spouses, and friends, as we learned by the end of Iliad 9. In other words, there is an exact analogue between daughter and mother on the one hand, and Patroklos/Achilles and the father of each on the other. ${ }^{11}$ (I have more to say below about the metonymic relationship between these two heroes, which is already implied by the equivalency between them in Achilles' words and by their philotês, which, as discussed above, is a term that applies to a metonymic relation between individuals as it does between a person and his or her own body parts.)

\footnotetext{
${ }^{10}$ Gaca, 2008, p. 156.

${ }^{11}$ I note in passing that in the Homeric simile closest in context and theme to this one, by Gaca's analysis, Odyssey 8.523-531, that compares a woman who embraces her fallen husband before her defeated city, her tears and lamenting cries, to Odysseus weeping at the singer Demodokos' tale of the capture of Troy, it is not a simple coincidence that the relation between tenor and vehicle crosses the gender boundary in the same way as Achilles' simile about the girl and her mother does. In itself, that consistency is also a mark of the integration of similes into the system of epic diction, though there is much to say about the gender-associations of lament in Epic.
} 
One other aspect of the diction relates directly to this point, namely, the word nēpie, in this part of the simile, lines 8-9:

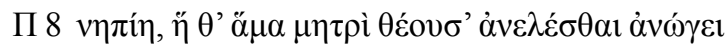

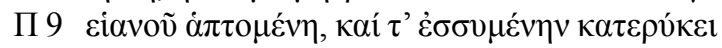

16.8 a nēpiè one, who running alongside her mother, begs her to pick her up 16.9 attaching herself to [haptomenē] her fine robe [heianou], and she tries to stop her rushing

The word nēpiè is usually translated 'foolish,' as in the Hesiodic proverb that I cited

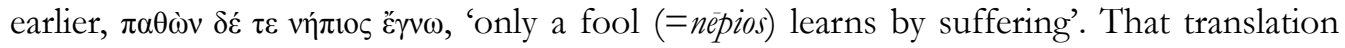
is based on a false etymology from *ne- 'not' and *wep- 'word' via the concept of 'not speaking' that we see in Latin infans (from in- 'not' and for, fari 'speak'), taking off from the general concept of infant and thence to the concept of foolishness - but as a colleague of mine, Susan Edmunds, pointed out in her doctoral dissertation, that semantic shift never actually happens in Latin. ${ }^{12}$ Surveying all the examples of both neppios and the positive form that is associated with it, eptios, she shows that they both having no essential connection with speaking ability or emotional maturity - the underlying and unifying semantic field of the word is connectedness to parents and the social norms that they embody and transmit. She suggested that an etymology from a root meaning 'join' or 'attach' suits the attestations in

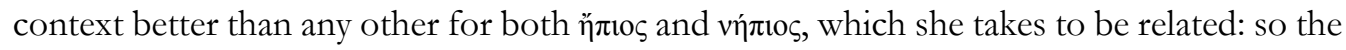
root of Sanskrit äpnoti and Latin apiö/apiscor and its derivatives aptus 'connected, suitable, appropriate' and ineptus 'disjointed, foolish' are possible cognates that work phonologically and semantically in parallel to the Homeric data. On the other hand, the root of Greek

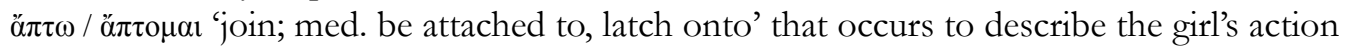
in the simile is not likely to be related to these Latin roots due to a lack of evidence for the aspiration of $\alpha \pi \tau \omega$ in them. Even so, the semantic undertone is real and may well be alive in the text. One can see the same undertone in the following passage, where Athena disguised as Mentor urges young Telemachus to grow up:

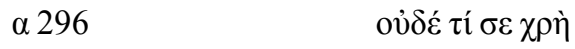

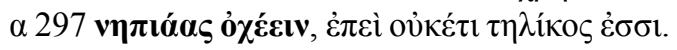

Od. $1.296 \quad$ it is no longer necessary

Od. 1.297 that you keep hold of nēpiāass (= 'the state of being detached')

The notion that a young person at the point of transition into adulthood will 'hold onto being detached' is on this interpretation an oxymoron - and one that still rings true. The semantic field of attachment to parents also clarifies why the word neppios is so often

\footnotetext{
${ }^{12}$ Edmunds, 1990, who points out that the Latin word infans never has the sense 'puerile' that some ascribe to Greek vímıs.
} 
(though by no means solely) associated with children, who after all are yet to be acculturated, whereas the word eppios by contrast is associated with the knowledge that a father embodies. ${ }^{13}$

Keeping this network of associations in mind, the girl in the simile is qualified with the word nepie because she is terrified of being detached - both physically and emotionally - from her mother, so she is trying to get physically connected to her by attaching herself to her garment. The semantics of attachment and detachment gives depth to the image, to the fear of bereavement which in this context is simply permanent detachment. It also perfectly suits the representation of Patroklos himself, who is about to be called mega neppios 'greatly disconnected' by the master narrator a few verses below for asking Achilles to give him his armor and an opportunity to fight and push back the Trojans from the ships:

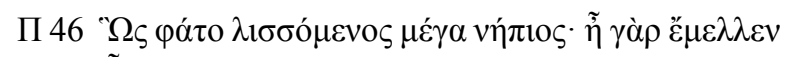

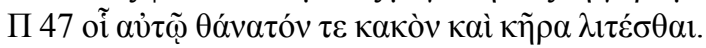

16.46 So he spoke, pleading, greatly nëpios; since he was in fact destined 16.47 to be begging for his own bad death and doom.

The semantics of attachment bring us back to one of my starting points, the nature of metonymy as opposed to metaphor, a reference to one thing by way of another thing connected or attached to it, as opposed to a reference to something like but also unlike it. I want to make a detour into an unusual area before I come back to that subject and conclude - in fact, my detour will also lead directly to metonymy and metaphor.

My starting point for this detour is the fine garment, the eiavós, that the girl latches onto in her attempt to hold back her mother and get picked up and that appears to be a superfluous element in the simile. Kathy Gaca cannot explain its relevance, but she does point out (p. 159, n. 40) that in Euripides' Trojan Women, when the chorus describes its being surprised by an ambush of Greek warriors, the children are also latching onto their mothers' robes (here peplous):

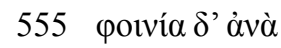

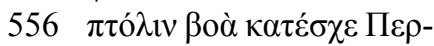

$557 \gamma \dot{\alpha} \mu \omega v \ddot{\varepsilon} \delta \rho \alpha \varsigma \cdot \beta \rho \varepsilon ́ \varphi \eta \delta \dot{\varepsilon} \varphi \dot{i} \lambda_{1-}$

$558 \alpha \pi \varepsilon \rho \grave{i} \pi \dot{\varepsilon} \pi \lambda$ ouৎ

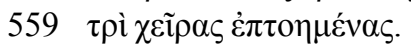

A bloody cry throughout | the city gripped Pergama's | halls; beloved children | threw round their mothers' robes | their trembling hands.

I expect that many of those who have been parents and some of us when we were children can remember a traumatic moment when a child was clinging to its parent's clothing while the parent was trying to get away. What I wish to adduce here is an article on what

\footnotetext{
${ }^{13}$ For example in the expression vท́лı

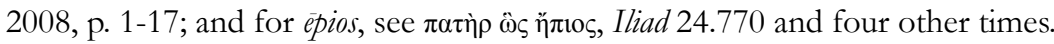


he called "transitional objects" by the British pediatric psychoanalyst D. W. Winnicott. His work brilliantly illuminates those moments in a way that relates directly to the Homeric simile and the literary and psychological concepts of metonymy and metaphor. ${ }^{14}$ Winnicott's goal is to describe an infant's psychological development into a distinct person, separate both from its mother and from the external world. Apparently, the standard view in the psychiatric literature is that a newborn's world is a continuous one, lacking in the perception of boundaries between itself and the external world. Under normal circumstances, given what Winnicott unromantically calls a "good enough" mother, there is no reason for an infant to perceive even its mother or her breast, its main point of contact with her, as distinct from itself. Most of the time when the child wants it, it is there. However, when the process of weaning begins, and sometimes a bit before, that nearness begins to change, and the child begins to come to grips with the reality that its mother and itself are separate. Winnicott says that what he calls transitional phenomena begin to take place in an infant anywhere between 4 and 12 months of age, in what he calls "an intermediate area of experience," "between the thumb and the teddy bear," 15 between the internal world of the child and the external world of objects and other people.

Here is what he says about this third domain, neither its own nor its mother's, of the life of a new human being:

[... it is] a part that we cannot ignore, an intermediate area of experiencing, to which inner reality and external life both contribute. It is an area which is not challenged, because no claim is made on its behalf except that it shall exist as a resting-place for the individual engaged in the perpetual human task of keeping inner and outer reality separate yet inter-related [...]. I am here staking a claim for an intermediate state between a baby's inability and growing ability to recognize and accept reality. I am therefore studying the substance of an illusion, that which is allowed to the infant, and which in adult life is inherent in art and religion. ${ }^{16}$

For Winnicott, this transitional mental space in the infant is in fact the origin of our ability to fantasize, and eventually in the adult it "widens out into...play, artistic creativity, religious feeling, and dreaming", as Winnicott puts it. What are the transitional phenomena and the transitional objects in this third realm for the child? The simplest example is the blanket or special piece of cloth that at anxious moments, such as before going to sleep, some infants and children hold between thumb and mouth; or some children pluck at the wool on their bed-clothing blankets and collect it into a ball for this purpose. Winnicott speculates that this may be the origin of the term 'wool-gathering', designating a state of mind which

\footnotetext{
${ }^{14}$ Winnicott, 1953 , p. 89-97.

${ }^{15}$ Winnicott, 1953 , p. 89.

${ }^{16}$ Winnicott, 1953, p. 90.
} 
is neither here nor there and which Winnicott describes as "inhabiting the transitional area". Here is what Winnicott says about the blanket in this constellation:

It is true that the piece of blanket (or whatever it is) is symbolical of some part-object, such as the breast. Nevertheless, the point of it is not its symbolic value so much as its actuality. Its not being the breast or the mother is as important as the fact that it stands for the breast or the mother. ${ }^{17}$

The key characteristic of the transitional object is its contradictory quality as at once separate from the child and not distinct from it. My final citation from his work is as follows:

[...] the term transitional object, according to my suggestion, gives room for the process of becoming able to accept difference and similarity. I think there is use for a term for the root of symbolism in time, a term that describes the infant's journey from the purely subjective to objectivity; and it seems to me that the transitional object is what we see of this journey of progress towards experiencing $[\ldots]$. It seems that symbolism can only be properly studied in the process of the growth of an individual, and that it has at the very best a variable meaning. For instance, if we consider the wafer of the Blessed Sacrament, which is symbolic of the body of Christ, I think I am right in saying that for the Roman Catholic community it is the body, and for the Protestant community it is a substitute, a reminder, and is essentially not, in fact, actually the body itself. ${ }^{18}$

This is what I meant when I said earlier that metonymy is a precursor to metaphor in the ontogenetic sense for every human growing up. In terms of the symbolism, as Winnicott calls it, of art, and in this case in terms of the tropes of metonymy and metaphor, Winnicott's psychological discussion of the transitional world of an infant can be translated into the transition from a metonymic relationship, when the child and the mother are attached to each other and continuous with one another to one in which a child sees its mother as separate from itself. The process of self-definition takes place by way of the transitional object, a blanket or a piece of cloth or a teddy bear, that is at times a metonym and at other times a metaphor and also, at time, just an object in itself devoid of symbolic content; there is also a transitional space, an entirely fantastical mind zone between the blanket and the mouth of the child.

The symbolic world that the image of the weeping girl inhabits is this transitional space, in which the girl is trying desperately to hold onto a metonymic relationship to her mother by way of her mother's robe, a transitional object that is both her mother and an external item connected to her mother. We can also now see that this metonymic relationship

\footnotetext{
${ }^{17}$ Winnicott, 1953 , p. 91-92.

${ }^{18}$ Winnicott, 1953, p. 97.
} 
is enclosed in a simile that constitutes a metaphor establishing a relationship of likeness and difference between the image of the girl and both Patroklos and Achilles - just as I spoke earlier of the metaphorical description of a metonymic relationship between individuals 'attached at the hip', the relationship between tenor and vehicle metaphorizes the metonymic relationship between Achilles (the mother) and Patroklos (the child) - and this in the context of what Gaca calls secondary warfare, the terrified flight of a mother from a future of enslavement and abuse that threatens to detach her from her own daughter.

I spoke a moment ago of the intense fear of bereavement, of permanent detachment from a person to whom one is deeply connected emotionally, embedded in Achilles' representation of Patroklos' tears and of their immediate cause, his concern about the imminent death of either of their parents or of their comrades-in-arms. But the image of the crying girl has a further and broader application, as a representation of Achilles' whole relationship to Patroklos and of his to Achilles. In this context, we can even point to another transitional object (like the mother's robe or a child's blanket) that connects the two in a literal way: the armor of Achilles that Patroklos will wear, and that Apollo violently and magically strips from his body at the end of Iliad 16 (793-804), beginning with the helmet that rolls in the blood and dust. In fact, the real question to ask now is: "does Achilles see himself and Patroklos as anything other than metonymically attached?" In fact, it all began in Iliad 11 with a metonymy. Achilles had been watching the Achaeans lose the battle from his hut, and he sent his beloved companion to Nestor to find out something important:

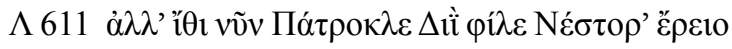

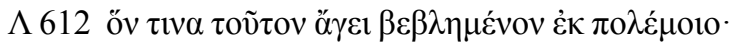

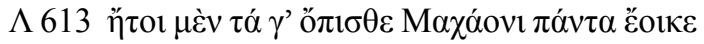

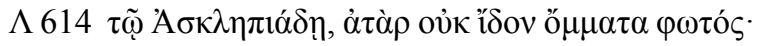

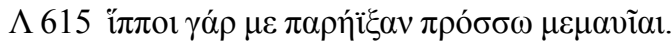

11.611 But go now, Patroklos dear to Zeus, and ask Nestor

11.612 who this wounded man was whom he was bringing out of the fighting.

11.613 From behind it certainly looked like Makhaon in every way,

11.614 the son of Asklepios, but I did not see the man's eyes,

11.615 because horses rushing forward darted past me.

This metonymy resembles the words of the little girl at dinner who sought to identify another person by their nearness to her mother's eyes. In fact, it turns out that the wounded warrior was Makhaon, and the moment is decisive, because the wounding of the army's healer is in itself a metonymic disaster, if not a literal one as well, for the whole host of fighting men. But back in Iliad 16, in the long speech that Achilles makes in response to Patroklos' request that Achilles allow him to dress up in his armor that follows on the simile, there is an expressive and excessive concentration of metonyms. The first one is applied to Achilles himself, then there are metonyms for Diomedes, Agamemnon, and lastly Hector. Here is the passage: 


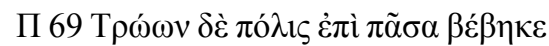

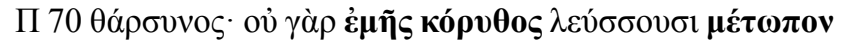

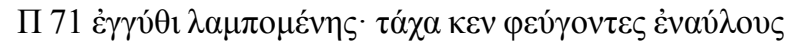

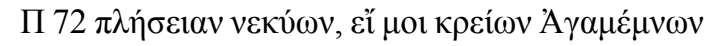

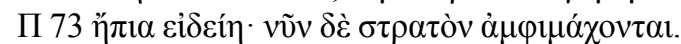

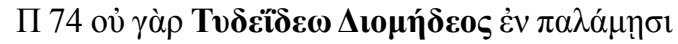

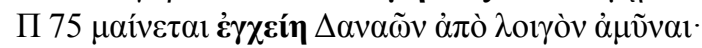

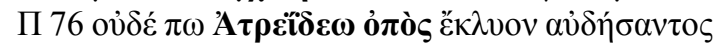

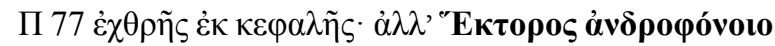

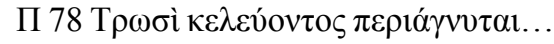

69 The whole city of the Trojans has come at them [the Argives],

70 emboldened; for they do not see the brow [metōpon] of my helmet

71 shining nearby: perhaps in their flight they would

72 fill the riverbeds with corpses, if mighty Agamemnon

73 had solidarity with me; but now their battle surrounds the camp.

74 For in the hands of Diomedes son of Tydeus

75 a spear does not rage to ward off destruction from the Danaans,

76 nor even do they ever hear the voice of the son of Atreus speaking

77 from his hostile head: but [the voice] of man-slaying Hector

78 giving orders to the Trojans breaks out all around...

The first of these metonyms, the one that describes the absent metopon of Achilles' helmet as inciting the whole Trojan polis against the Argives, is striking all by itself, since it also supplies the metonymic logic of Achilles' positive response in this speech to Patroklos' request that he dress in Achilles' armor and push the Trojans back: if the absence of Achilles' helmet emboldens the Trojans, then the presence of that helmet should produce the intended opposite effect. (Incidentally, it is also a metonym of a metonym of a metonym - the metopon standing for the helmet as a whole which stands for the whole suit of armor). The other metonyms are for the other absent Achaeans, the wounded warriors; by contrast, the only non-absent one is the threatening voice of Hector. Clearly, Achilles is speaking of the world as consisting of things that are attached to people - helmet, spear, voices - rather than of humans themselves as agents.

It has long since been made clear by others that the relationship of philotés, of attachment or the affection that it implies, has deep historical roots in the development of the epic tradition about these two heroes. Patroklos, who is specified as Achilles' therapon in the sense of his 'sidekick' or 'attendant' (Iliad 16.165 etc.), still also plays the role of his ritual substitute. That in fact was the meaning of the Bronze Age borrowing of an Anatolian root *tarpan from which the word therapoin derives, namely, a figure who dressed as the king and was then ritually slain to purify the kingdom. ${ }^{19}$ Furthermore, the description of Patroklos' exploits and death in Iliad 16 is a montage on the death of Achilles as it can be reconstructed

$\overline{{ }^{19} \text { Van Brock, 1959 }}$, p. 117-146; see also Lowenstam, 1981 etc. 
from the fragments of the Aethiopis. ${ }^{20}$ Much more can be said on this topic, but it is fair to say that Patroklos readily takes on the identity of Achilles along with his armor, and he takes it on, if anything, too well. So the metonymic relationship that Achilles expresses for his beloved companion and that is signaled in the simile of the weeping girl grasping her fleeing mother's robe is deeply supported in this Homeric text. But it is also true, to return to the transitional process described by Winnicott, that Achilles can get past the metonymic worldview and speak of his companion in an objective way, as a person distinct from himself, or as Winnicott would say, both like and unlike him. Consider these remarks toward the end of the same speech:

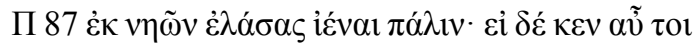

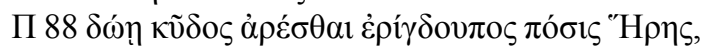

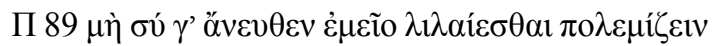

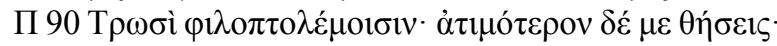

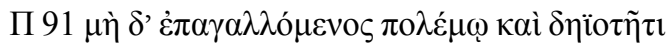

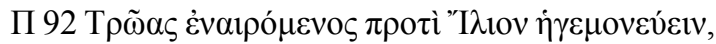

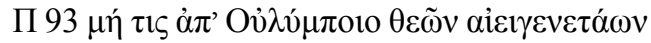

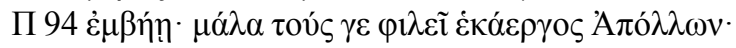

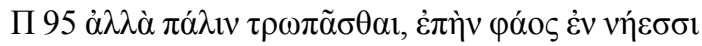

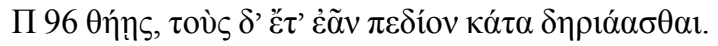

16.87 once you drive [the Trojans] from the ships, come back; and if in turn

16.88 the loud-resounding spouse of Hera grants you to win glory,

16.89 do not yearn to fight on without me

16.90 against the war-loving Trojans; you will make me more dishonored;

16.91 and don't, caught up in war and combat

16.92 and slaying Trojans, lead them all the way to Ilion,

16.93 lest one of the everlasting gods from Olympus

16.94 steps in: Apollo who works from afar really loves them;

16.95 but turn back once, among the ships,

16.96 you make space and light, and leave them to fight on over the plain.

Here Achilles is clairvoyant about the disaster that will befall his companion if he goes too far and gets carried away in his sole exploit. But then, at the very end of this same speech, with the worry about Patroklos' separation and return once again in mind, Achilles actually switches into the realm of transitional space, that of pure fantasy, as follows:

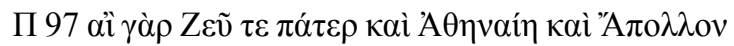

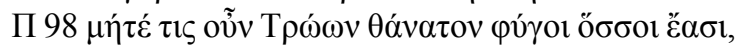

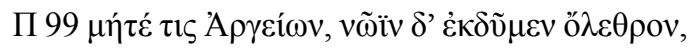

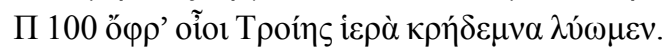

\footnotetext{
${ }^{20}$ As demonstrated by Pestalozzi, 1945.
} 
97 dear Zeus father and Athena and Apollo, if only

98 neither any of the Trojans, as many as they are, would flee death,

99 nor any of the Argives, but the two of us escape destruction,

100 so that we alone might loosen the sacred veils of Troy.

Wishes preceded by the invocation of Zeus, Athena, and Apollo are the epic's conventional way of expressing admittedly unfulfillable, altogether fantastic ideas, as when Nestor wishes he had the fighting strength of an 18 -year old. ${ }^{21}$ So here, Achilles is imagining his fusion with his best friend, in victory, and in a danger-free zone, with all of the warriors on the conflicting sides dead and gone, a scene very far indeed from the 'reality' that awaits them both.

It seems to me remarkable and beyond coincidence that the three stages of Winnicott's transitional process are evoked so clearly in the speech of Achilles that follows the one with the simile of the weeping girl, an image that depicts the trauma of detachment in the psychology of a young child. I suggest that Winnicott's idea is a key to the simile and that it points to a new way in which we can view the relationship between Achilles and Patroklos. Instead of seeing the epic hero's decision to accept his friend's request to go out on his own and save the day as the disastrous moral error of a stubborn and angry man, of a flawed and deluded character, we can view it as the gesture of a man granting his best friend the chance to act on his own, with the agency and responsibility for his own empathic but mistaken choice that the master narrator grants him, but at one and the same time demonstrating the deep attachment, the objective and helpful concern, and also the fantasy of a child in transitional space. In short, given his metonymic relationship to Patroklos, given their metaphoric equivalence to each other, Achilles is every bit as much the tenor of the simile at the start of Iliad 16 as is his beloved companion.

\section{REFERENCES}

BLACK, M. Models and Metaphors: Studies in Language and Philosophy. Ithaca: Cornell University Press, 1962.

EDMUNDS, S. Homeric Nēpios. New York: Garland Publishing, 1990. http://nrs.harvard. edu/urn-3:hul.ebook:CHS_EdmundsS.Homeric_Nepios.1990

GACA, K. The Little Girl and Her Mother: Iliad 16.7-11 and Ancient Greek Warfare. American Journal of Philology, v. 129, p. 145-171, 2008.

GOODMAN, N. Languages of Art: An Approach to a Theory of Symbols. Indianapolis: BobbsMerrill Company, 1968.

${ }^{21}$ Iliad 7,132-158; for more examples of the invocation of these three gods to visualize a fantasy, compare Iliad 2.371-380 and 4.288-291, and Odyssey 4.341-346, 7.311-316, 17.132-137, 18.235-242, and 24.376-382. 
LORD, A. B. Homer as Oral Poet. Harvard Studies in Classical Philology, v. 72, p. 1-46, 1968.

LOWENSTAM, S. The Death of Patroklos: A Study in Typology. Königstein/Ts.: Hain, 1981.

MUELLNER, L. The Simile of the Cranes and Pygmies. Harvard Studies in Classical Pbilology, v. 93, p. 59-101, 1990. http://nrs.harvard.edu/urn-3:hlnc.essay:Muellner.The_Simile_of_ the_Cranes_and_Pygmies.1990 (last accessed 10.2019).

NAGY, G. Masterpieces of Metonymy: From Ancient Greek Times to Now. Washington DC: The Center for Hellenic Studies, 2016. http://nrs.harvard.edu/urn-3:hul.ebook:CHS_Nagy. Masterpieces_of_Metonymy.2015 (last accessed 10.2019).

PESTALOZZI, H. Die Achilleis als Quelle der Ilias. Ehrlenback-Zürich: Eugen Rentsch Verlag, 1945.

RICHARDS, I. A. The Philosophy of Rhetoric. Oxford: Oxford University Press, 1971 [1936].

SCOTT, W. C. The Artistry of the Homeric Simile. Hanover: Dartmouth College Press, 2009. https://www.dartmouth.edu/ library/digital/publishing/scott2009/ (last accessed 10.2019).

SCOTT, W. C. The Oral Nature of Homeric Similes. Leiden: Brill, 1974.

VAN BROCK, N. Substitution rituelle. Revue Hittite et Asianique, v. 65, p. 117-146, 1959.

WERNER, C. Wives, Widows and Children: War Victims in IliadBook II. L'Antiquité Classique, v. 77 , p. $1-17,2008$.

WINNICOTT, D. Transitional Objects and Transitional Phenomena: A Study of the First Not-Me Possession. International Journal of Psycho-Analysis, v. 34, p. 89-97, 1953. 